\title{
HOXB13 wt Allele
}

National Cancer Institute

\section{Source}

National Cancer Institute. HOXB13 wt Allele. NCI Thesaurus. Code C112823.

Human HOXB13 wild-type allele is located in the vicinity of $17 q 21.32$ and is approximately

$4 \mathrm{~kb}$ in length. This allele, which encodes homeobox protein Hox-B13, plays a role in transcriptional regulation. 